University of Nebraska - Lincoln

DigitalCommons@University of Nebraska - Lincoln

\title{
The persistence of lead from past gasoline emissions and mining drainage in a large riparian system: Evidence from lead isotopes in the Sacramento River, California
}

\author{
C. E. Dunlap \\ University of California - Santa Cruz, cdunlap@es.ucsc.edu \\ Charles N. Alpers \\ U.S. Geological Survey, cnalpers@usgs.gov \\ R. Bouse \\ US Geological Survey \\ H. E. Taylor \\ US Geological Survey, hetaylor@usgs.gov \\ D. M. Unruh \\ US Geological Survey \\ See next page for additional authors
}

Follow this and additional works at: https://digitalcommons.unl.edu/usgsstaffpub

Part of the Earth Sciences Commons

Dunlap, C. E.; Alpers, Charles N.; Bouse, R.; Taylor, H. E.; Unruh, D. M.; and Flegal, A. R., "The persistence of lead from past gasoline emissions and mining drainage in a large riparian system: Evidence from lead isotopes in the Sacramento River, California" (2008). USGS Staff -- Published Research. 480.

https://digitalcommons.unl.edu/usgsstaffpub/480

This Article is brought to you for free and open access by the US Geological Survey at DigitalCommons@University of Nebraska - Lincoln. It has been accepted for inclusion in USGS Staff -- Published Research by an authorized administrator of DigitalCommons@University of Nebraska - Lincoln. 
Authors

C. E. Dunlap, Charles N. Alpers, R. Bouse, H. E. Taylor, D. M. Unruh, and A. R. Flegal

This article is available at DigitalCommons@University of Nebraska - Lincoln: https://digitalcommons.unl.edu/ usgsstaffpub/480 


\title{
The persistence of lead from past gasoline emissions and mining drainage in a large riparian system: Evidence from lead isotopes in the Sacramento River, California
}

\author{
C.E. Dunlap ${ }^{\mathrm{a}, \mathrm{b}, *}$, C.N. Alpers $^{\mathrm{c}}$, R. Bouse ${ }^{\mathrm{d}}$, H.E. Taylor ${ }^{\mathrm{e}}$, D.M. Unruh ${ }^{\mathrm{f}}$, A.R. Flegal $^{\mathrm{a}}$ \\ ${ }^{a}$ Environmental Toxicology, 430 Physical Sciences Bldg., University of California, Santa Cruz, CA 95064, USA \\ ${ }^{\mathrm{b}}$ US Civilian Research \& Development Foundation, 1530 Wilson Blvd., 3rd Fl., Arlington, VA 22209, USA \\ ${ }^{\mathrm{c}}$ US Geological Survey, 6000J Street, Placer Hall, Sacramento, CA 95819, USA \\ ${ }^{\mathrm{d}}$ US Geological Survey, 345 Middlefield Road, Menlo Park, CA 94025, USA \\ ${ }^{\mathrm{e}}$ US Geological Survey, 3215 Marine Street, Boulder, CO 80303, USA \\ ${ }^{\mathrm{f}}$ US Geological Survey, Denver Federal Center, Denver, CO 80225, USA
}

Received 5 February 2008; accepted in revised form 7 October 2008; available online 17 October 2008

\begin{abstract}
Lead concentrations and isotope ratios measured in river water colloids and streambed sediment samples along $426 \mathrm{~km}$ of the Sacramento River, California reveal that the influence of lead from the historical mining of massive sulfide deposits in the West Shasta Cu-mining district (at the headwaters of the Sacramento River) is confined to a $60 \mathrm{~km}$ stretch of river immediately downstream of that mining region, whereas inputs from past leaded gasoline emissions and historical hydraulic Au-mining in the Sierra Nevadan foothills are the dominant lead sources in the remaining $370 \mathrm{~km}$ of the river. Binary mixing calculations suggest that more than $50 \%$ of the lead in the Sacramento River outside of the region of influence of the West Shasta Cu-mining district is derived from past depositions of leaded gasoline emissions. This predominance is the first direct documentation of the geographic extent of gasoline lead persistence throughout a large riparian system $\left(>160,000 \mathrm{~km}^{2}\right)$ and corroborates previous observations based on samples taken at the mouth of the Sacramento River. In addition, new analyses of sediment samples from the hydraulic gold mines of the Sierra Nevada foothills confirm the present-day fluxes into the Sacramento River of contaminant metals derived from historical hydraulic Au-mining that occurred during the latter half of the 19 th and early part of the 20th centuries. These fluxes occur predominantly during periods of elevated river discharge associated with heavy winter precipitation in northern California. In the broadest context, the study demonstrates the potential for altered precipitation patterns resulting from climate change to affect the mobility and transport of soil-bound contaminants in the surface environment.
\end{abstract}

(c) 2008 Elsevier Ltd. All rights reserved.

\section{INTRODUCTION}

The global biogeochemical cycling of lead is dominated by human emissions (Patterson, 1965; Patterson et al., 1976; Shirahata et al., 1980). Emissions of lead from com-

\footnotetext{
* Corresponding author. Address: Environmental Toxicology, 430 Physical Sciences Bldg., University of California, Santa Cruz, CA 95064, USA.

E-mail address: cdunlap@es.ucsc.edu (C.E. Dunlap).
}

bustion of leaded gasoline have accounted for $75 \%$ of total global emissions since the early 20th century, and over the same period the mining of lead-bearing ores has increased (Nriagu and Pacyna, 1988; Nriagu, 1990; Flegal and Smith, 1995). Few lead isotope studies have addressed the influence of acid mine drainage from lead mines in riparian systems beyond $40 \mathrm{~km}$ downstream (e.g., Church et al., 1994, 1999, 2004, 2007; Nordstrom et al., 2000; Schemel et al., 2000), and in none of those studies has the riverborne transport of lead from gasoline emissions been compared to the transport of lead from acid mine drainage.

0016-7037/\$ - see front matter (c) 2008 Elsevier Ltd. All rights reserved. doi:10.1016/j.gca.2008.10.006 
The present study compares the transport of lead from acid mine drainage, Sierra Nevada hydraulic Au-mining sediment, and historical leaded gasoline emissions throughout a drainage basin encompassing more than $160,000 \mathrm{~km}^{2}$ : the Sacramento River system of northern California.

In California, gasoline-derived lead emissions have been estimated to be $90 \%$ of the total lead flux, a figure greater than the global average of $75 \%$ due to the historically large number of cars in the state (Nriagu, 1990; Steding et al., 2000). The sale of leaded gasoline for automobiles ended in California in 1992, but the release of that gasoline lead bound in drainage basin soils and streambed sediments may take decades if not centuries (Dunlap et al., 2000; Steding et al., 2000). This slow transport of contaminant lead out of the Sacramento River system, which drains $40 \%$ $\left(164,420 \mathrm{~km}^{2}\right)$ of the land surface area in California, has been inferred from previous work in the waters of the northern reach of San Francisco Bay estuary, where the river enters the estuary and mixes with a saline wedge of North Pacific Ocean water (Ritson et al., 1999; Dunlap et al., 2000; Steding et al., 2000).

To document lead sources and dynamics of transport in the Sacramento River upstream of the San Francisco Bay estuary, we have collected a set of samples along the $426 \mathrm{~km}$ length of the river downstream of Shasta Dam to the city of Freeport, $74 \mathrm{~km}$ from the river's mouth. Measurements of lead concentrations and isotopic compositions in samples of streambed sediment and suspended colloid material in water allowed us to numerically model the removal of localized lead inputs from the West Shasta $\mathrm{Cu}-$ mining district, to better define the lead isotope composition of hydraulic Au-mining sediments of the Sierra Nevada foothills and their influence on lead compositions in the Sacramento River system, and to quantify the presence of lead from past gasoline emissions throughout the drainage basin.

\section{BACKGROUND}

Sediment cores dated by radiochemical methods from the northern reach of the San Francisco Bay estuary, where the waters of the Sacramento River enter the Bay, chronicle the historical fluxes of natural and industrial lead flowing out of the Sacramento River and distinguish the sources of these fluxes by their isotopic compositions (Ritson et al., 1999). The lead isotope signature of pre-anthropogenic river sediment is recorded at the base of the cores in samples older than $1800 \mathrm{AD}\left({ }^{206} \mathrm{~Pb} /{ }^{207} \mathrm{~Pb}=1.215-1.225\right.$ and $\left.{ }^{208} \mathrm{~Pb} /{ }^{207} \mathrm{~Pb}=2.480-2.488\right)$. These lead isotope ratios are interpreted to represent the natural composition of lead transported to the mouth of the Sacramento River: lead derived from rock weathering in the drainage basin prior to the onset of industrial-age human activity in the system (Ritson et al., 1999; Dunlap et al., 2000). These interpreted pre-anthropogenic lead isotope ratios fall within the range of measured lead isotope ratios in the rocks of the Sierra Nevada mountains (e.g., Chen and Tilton, 1991; Wenner and Coleman, 2004).

The first perturbation of the natural lead isotope ratio occurred from 1852 to 1914 when sediment loads in the Sac- ramento River increased by 10 -fold due to the influx of sediment from the hydraulic mining of placer gold deposits in the foothills of the Sierra Nevada (Nichols et al., 1986; Dunlap et al., 2000). The isotopic signature of that hydraulic Au-mining sediment is partially masked in the sediment core record by lead emissions from a lead smelter that operated nearby the core sites (Ritson et al., 1999). However, subsequent studies determined that the lead from hydraulic Au-mining sediment is a mixing end-member in waters of the combined Sacramento/San Joaquin River delta sampled in the 1990s (Dunlap et al., 2000; Steding et al., 2000). The lead isotope ratios of the hydraulic Au-mining end-member were directly measured $\left({ }^{206} \mathrm{~Pb} /{ }^{207} \mathrm{~Pb}=1.220-1.245\right.$ and $\left.{ }^{208} \mathrm{~Pb} /{ }^{207} \mathrm{~Pb}=2.500-2.515\right)$ in two samples from the Malakoff Diggins, the largest of the hydraulic gold mines in the Sierra Nevadan foothills, located on the Yuba River (Fig. 1).

In addition to the hydraulic, placer gold mines in the Sierra Nevadan foothills, hard-rock Cu-mining of the volcanogenic massive sulfide deposits was active from the 1860 s to the 1960 s in the West Shasta mining district in the northern part of Sacramento River drainage basin (Fig. 1; Nordstrom and Alpers, 1999; Nordstrom et al., 2000; Alpers et al., 2003, and references therein). The West Shasta mining district encompasses the mines of the Iron Mountain mining district, the largest in the West Shasta region, whose runoff drains into the Keswick Reservoir, and smaller mines whose runoff drains into the Lake Shasta reservoir. The Devonian-age, Kuroko-type massive sulfide deposits were mined primarily for copper, silver, and pyrite, and contain minor amounts ( $\leqslant 5 \%$ by volume) of lead sulfide minerals. Despite this relatively high lead content, the low lead isotopic ratios of the West Shasta ores and mining waste $\left({ }^{206} \mathrm{~Pb} /{ }^{207} \mathrm{~Pb} \leqslant 1.166\right.$; Doe et al., 1985) are not evident in the river-mouth sediment core record (Ritson et al., 1999): the ${ }^{206} \mathrm{~Pb} /{ }^{207} \mathrm{~Pb}$ ratios of river-mouth sediments do not fall below 1.215 at any time before the $1940 \mathrm{~s}$.

The second perturbation to lead source and isotopic composition in the Sacramento River did not come until the late 1940s with the onset of the large-scale use of lead alkyl additives to gasoline. Dated sediment cores record this onset as the first time that the ${ }^{206} \mathrm{~Pb} /{ }^{207} \mathrm{~Pb}$ ratio fell below 1.215 and lead concentrations rose by more than a factor of two: the largest perturbation to lead concentrations and isotopic compositions during the past 1000 years in the Sacramento River system (Ritson et al., 1999). This impact is attributed to the deposition in the Sacramento River drainage basin of more than 20 million kilograms of lead from gasoline emissions (Steding et al., 2000). The isotopic composition of lead alkyl additives changed from the late 1940 s through the 1980 s when their use was finally phased out (Dunlap et al., 2000; Steding et al., 2000, and references therein). The lead isotope composition of gasoline in California during the last half of the 20th century ranged from ${ }^{206} \mathrm{~Pb} /{ }^{207} \mathrm{~Pb}=1.14-1.23$ to ${ }^{208} \mathrm{~Pb} /{ }^{207} \mathrm{~Pb}=2.42-2.45$ (Dunlap et al., 2000; Steding et al., 2000, and references therein). Therefore, for the past 150 years the lead content of the Sacramento River has been dominated by hydraulic Au-mining sediment and deposits from leaded gasoline emissions, with the pre-anthropogenic terrestrial lead 


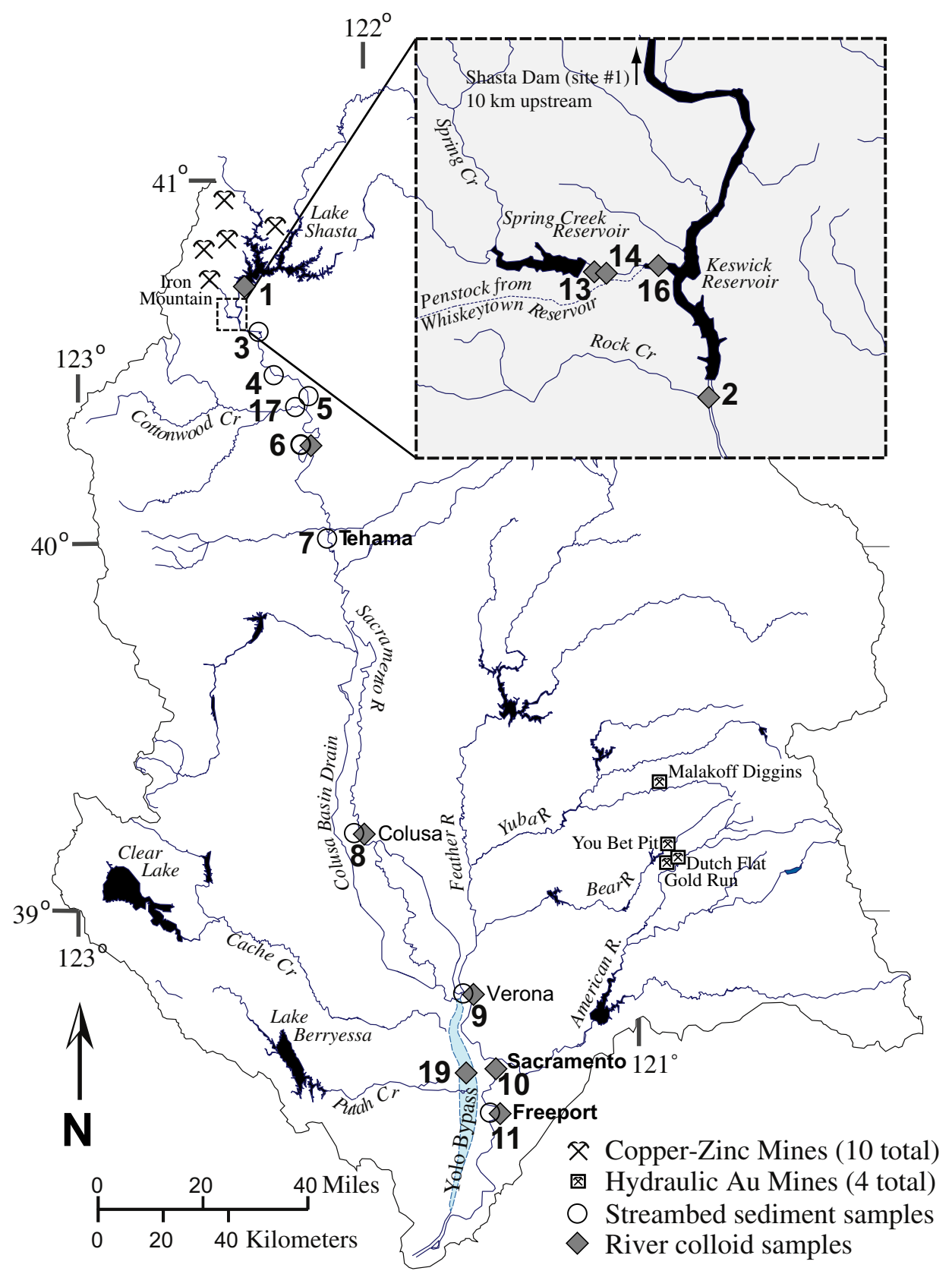

Fig. 1. Sampling sites along the Sacramento River, tributaries, and Yolo Bypass distributary. Site names and numbers (unless otherwise noted, the sample location is on the Sacramento River): 1. below Shasta Dam; 2. below Keswick Dam; 3. at Rodeo Park near Redding; 4. above Churn Creek near Anderson; 5. at Balls Ferry; 6. above Bend Bridge; 7. at Tehama; 8. at Colusa; 9. at Verona; 10. at Tower Bridge; 11. at Freeport; 13. Spring Creek below Spring Cr. Debris Dam; 14. Spring Creek below Iron Mt. Road; 16. Keswick Reservoir, Spring Cr. arm; 17. Cottonwood Cr., near Cottonwood; 19. Yolo Bypass at I-80 near W. Sacramento. Hydraulic mining sample sites in the Bear River drainage basin (Dutch Flat, You Bet Pit, and Gold Run) and the Yuba River drainage basin (Malakoff Diggins) are also shown.

component no longer observed to influence the lead isotope composition of Sacramento River waters (Dunlap et al., 2000; Steding et al., 2000).

In addition to these century-scale changes in lead sources to the Sacramento River, decadal trends in those sources were observed in the 1990s (Steding et al., 2000). Samples of water taken from the mouth of the Sacramento River showed a progressive shift away from gasoline lead compositions and towards the hydraulic Au-mining end- member during the 1990s (Steding et al., 2000). Superimposed on that decadal trend were seasonal variations in lead isotopic compositions, with water samples collected during high-flow periods consistently higher in ${ }^{206} \mathrm{~Pb} /{ }^{207} \mathrm{~Pb}$ than those taken during low flow. This seasonal shift was attributed to the advection of 1980 s gasoline lead into the Sacramento River by elevated surface runoff during the high flow events (Steding et al., 2000). These decadal trends allowed refinement of the end-member mixing that appears to con- 
trol lead isotope compositions in the Sacramento River: the hydraulic Au-mining sediments mix with two components of leaded gasoline emissions, a 1980s component (bound in streambed sediments and the near-surface soils of the drainage basin) and a 1960-70s gasoline lead component (bound in streambed sediments and subsurface soils of the drainage basin) (Steding et al., 2000).

Consequently, the present study examines the lead concentration and isotopic composition of river water colloids and streambed sediment samples on a $426 \mathrm{~km}$ reach of the Sacramento River upstream of the delta region (Fig. 1). The geographic variation in lead sources to the river is used to test the validity of the sources inferred from previous research at the Sacramento River mouth, including historical gasoline emissions and hydraulic Au-mining sediment from the Sierra Nevada. In addition, we determine the downriver extent of contributions to lead load from another miningrelated source of lead: the massive sulfide deposits of the West Shasta $\mathrm{Cu}$-mining district in the upper Sacramento River watershed. By combining the chronological studies from the San Francisco Bay estuary with this geographic study, an integrated view of contaminant lead movement in the Sacramento River basin is constructed.

\section{METHODS}

Samples of river water and streambed sediments were collected along a $426 \mathrm{~km}$ reach of the Sacramento River (Fig. 1). Samples were also collected in tributaries to the Sacramento River in the West Shasta Cu-mining district (Fig. 1, inset). Sediment samples were also collected at several locations in the Sierra Nevada hydraulic Au-mining region. All sampling and subsequent handling was done using trace metal clean techniques (Patterson et al., 1976; Alpers et al., 2000a). These techniques were comparable to those in our previous studies of lead isotope compositions in the lower reaches of the Sacramento River (Dunlap et al., 2000) and San Francisco Bay (Ritson et al., 1999; Steding et al., 2000).

The water sampling took place during December 1996 and January 1997. Flow conditions during December 1996 were typical of moderately high flow conditions in the early wet season, whereas flow conditions during January 1-3, 1997 were extremely high. The January 1997 conditions were characterized by elevated loads of lead, mercury, and other trace metals (Alpers et al., 2000b; Roth et al., 2001). Streambed sediment samples were collected during October and November 1996, prior to the wet season.

Water samples were filtered and ultra-filtered, and a size fraction in the range from 0.005 to $1 \mu \mathrm{m}$ was collected for analysis as representative of the colloidal component of the water. By comparison to whole water lead concentrations in unfiltered samples, we determined that the colloidal size fraction contained $\sim 80 \%$ of the lead, on average, in the river water. Previous work in the waters of San Francisco Bay and the river mouth demonstrated that lead isotopic equilibrium exists between filtered $(<0.45 \mu \mathrm{m})$ and unfiltered water fractions (Dunlap et al., 2000). The colloidal lead isotope analyses in this study, therefore, represented the majority of the lead carried by the water and may be di- rectly compared to whole water lead isotope compositions reported in previous studies.

Streambed sediments, hydraulic Au-mining sediments, and colloid samples were fully digested in hydrofluoric and nitric acids in preparation for concentration and isotopic analysis. Lead concentrations were measured by magnetic sector, high-resolution, inductively coupled mass spectrometry (HR ICP-MS). The reproducibility of concentration measurements for each sample was determined by triplicate analysis of each digest and was better than $5 \%$ relative standard deviation from the mean of the triplicate analyses with the exception of one streambed sediment sample (\#3) for which the error was 5.6\%.

To determine the accuracy of concentration measurements of lead in both river water colloids and streambed sediments, Standard Reference Materials (SRMs) certified by NIST were processed and analyzed with the samples (Alpers et al., 2000a). NIST SRMs for river water (1643a, $1643 \mathrm{~b}$, and $1643 \mathrm{~d})$ made up $30 \%(n=1984)$ of the river water colloid samples processed and analyzed in the laboratory during the period when the samples in this study were analyzed, and NIST SRMs for streambed sediments (1645 and 2704) made up 15\% $(n=19)$ of the streambed sediment samples processed and analyzed. In $97 \%$ of measurements of river water colloids, SRMs showed $85-115 \%$ recovery of lead, and $92 \%$ showed $90-110 \%$ recovery of lead. All streambed sediment SRM measurements showed 90-110\% recovery of lead. Field blanks and process blanks for lead were two to three orders of magnitude lower in concentration than concentrations measured in river water colloids, therefore no blank correction was applied to the measured concentrations (Alpers et al., 2000a).

Lead isotope compositions were analyzed by thermal ionization mass spectrometry (TIMS) using both a VG54R single-collector mass spectrometer and a Micromass Sector 54, 7-collector mass spectrometer. A subset of samples was run on both instruments, and no systematic biases were observed between the two instruments. Samples were corrected for mass fractionation of $0.13 \%(\mathrm{sd} \pm 0.02)$ per atomic mass unit based on replicate analyses of NIST SRM-981. Typical analytical uncertainties at the 95\% confidence interval are $\approx 0.08 \%$ relative standard deviation for ${ }^{206} \mathrm{~Pb} /{ }^{204} \mathrm{~Pb} ; \approx 0.04 \%$ for ${ }^{206} \mathrm{~Pb} /{ }^{207} \mathrm{~Pb}$; and $\approx 0.05 \%$ for ${ }^{208} \mathrm{~Pb} /{ }^{207} \mathrm{~Pb}$.

\section{RESULTS}

\subsection{Lead concentrations}

The streambed sediments and suspended colloidal material in water show geographic variation in their lead concentrations (Fig. 1 and Table 1). Lead concentrations of both colloids and streambed sediments diminish downstream of the $\mathrm{Cu}$-mining region (Fig. 2).

\subsubsection{Sacramento River water colloids}

Within $15 \mathrm{~km}$ of the $\mathrm{Cu}$-mining region, concentrations of lead in river water colloids decrease by a factor of four, dropping from a high of nearly $80 \mu \mathrm{g} / \mathrm{g}$ in Spring Creek to an average value of $21 \mu \mathrm{g} / \mathrm{g}(\mathrm{sd} \pm 2)$ along the $300 \mathrm{~km}$ of 
Table 1

Lead concentration and isotopic data. Upriver distance for Sacramento River samples is measured as distance upstream from the Sacramento River delta. Downriver distance is measured as distance from the farthest upstream sample, taken in the Sacramento River downstream from Shasta Dam.

\begin{tabular}{|c|c|c|c|c|c|c|c|c|}
\hline Sample \# & Sample type/name & Date & $\begin{array}{l}\text { Upriver } \\
(\mathrm{km})\end{array}$ & $\begin{array}{l}\text { Downriver } \\
(\mathrm{km})\end{array}$ & $\begin{array}{l}\mathrm{Pb} \\
(\mathrm{mg} / \mathrm{kg})\end{array}$ & $\begin{array}{l}{ }^{206} \mathrm{~Pb} / \\
{ }^{204} \mathrm{~Pb}\end{array}$ & $\begin{array}{l}{ }^{206} \mathrm{~Pb} / \\
{ }^{207} \mathrm{~Pb}\end{array}$ & $\begin{array}{l}{ }^{208} \mathrm{~Pb} / \\
{ }^{207} \mathrm{~Pb}\end{array}$ \\
\hline Sacrament & $\begin{array}{l}\text { River colloidal samples } \\
\text { Within Cu-Mining Region } \\
\text { Sacramento River sites }\end{array}$ & & & & & & & \\
\hline 1 & Below Shasta Dam & 12-Dec-96 & 500 & 0 & 40 & 18.661 & 1.1967 & 2.4444 \\
\hline 16 & Keswick reservoir at Spring Creek Arm & 11-Dec-96 & 489 & 11 & 62 & 18.135 & 1.1692 & 2.4304 \\
\hline 2 & Below Keswick Dam & 11-Dec-96 & 486 & 14 & 72 & 18.185 & 1.1728 & 2.4312 \\
\hline 2 & $\begin{array}{l}\text { Below Keswick Dam } \\
\text { Tributaries }\end{array}$ & 02-Jan-97 & 486 & 14 & 39 & 18.344 & 1.1819 & 2.4350 \\
\hline 13 & Spring Cr. below Spring Cr. debris dam & 11-Dec-96 & 489 & 11 & 76 & 18.103 & 1.1684 & 2.4282 \\
\hline 14 & $\begin{array}{l}\text { Spring Cr. below Iron Mt. Road } \\
\text { Outside Cu-Mining Region } \\
\text { Sacramento River sites }\end{array}$ & 02-Jan-97 & 489 & 11 & 49 & 18.079 & 1.1657 & 2.4277 \\
\hline 10 & At Tower Bridge & 06-Jan-97 & 90 & 410 & 33 & 19.115 & 1.2176 & 2.4985 \\
\hline 8 & At Colusa & 04-Jan-97 & 230 & 270 & 20 & 18.905 & 1.2097 & 2.4718 \\
\hline 6 & Above Bend Bridge & 03-Jan-97 & 415 & 85 & 24 & 18.866 & 1.2077 & 2.4681 \\
\hline 9 & At Verona & 18-Dec-96 & 126 & 374 & 22 & 18.808 & 1.2042 & 2.4673 \\
\hline 11 & At Freeport & 17-Dec-96 & 74 & 426 & 24 & 18.844 & 1.2049 & 2.4700 \\
\hline 8 & At Colusa & 16-Dec-96 & 230 & 270 & 19 & 18.792 & 1.2042 & 2.4654 \\
\hline 6 & $\begin{array}{l}\text { Above Bend Bridge } \\
\text { Distributary }\end{array}$ & 12-Dec-96 & 415 & 85 & 21 & 18.785 & 1.2041 & 2.4646 \\
\hline 19 & Yolo Bypass at 1-80 near W. Sacramento & 07-Jan-97 & 134 & 366 & 22 & 18.896 & 1.2094 & 2.4717 \\
\hline Sacrament & $\begin{array}{l}\text { River streambed sediment samples } \\
\text { Within Cu-Mining Region } \\
\text { Sacramento River sites }\end{array}$ & & & & & & & \\
\hline 3 & Rodeo Park & 23-Oct-96 & 479 & 21 & 36 & 18.234 & 1.1732 & 2.4344 \\
\hline 4 & Churn Creek & 22-Oct-96 & 459 & 41 & 36 & 18.354 & 1.1830 & 2.4470 \\
\hline \multirow[t]{2}{*}{5} & Balls Ferry & 22-Oct-96 & 444 & 56 & 24 & 18.704 & 1.1990 & 2.4608 \\
\hline & $\begin{array}{l}\text { Outside } \mathrm{Cu} \text {-Mining Region } \\
\text { Sacramento River sites }\end{array}$ & & & & & & & \\
\hline 6 & above Bend Bridge & 22-Oct-96 & 415 & 85 & 14 & 18.819 & 1.2063 & 2.4667 \\
\hline 7 & Tehama & 23-Oct-96 & 332 & 168 & 14 & 18.823 & 1.2073 & 2.4657 \\
\hline 8 & Colusa & 14-Nov-96 & 230 & 270 & 12 & 18.871 & 1.2096 & 2.4692 \\
\hline 9 & Verona & 13-Nov-96 & 126 & 374 & 19 & 18.874 & 1.2079 & 2.4697 \\
\hline 11 & $\begin{array}{l}\text { Freeport } \\
\text { Tributary }\end{array}$ & 15-Nov-96 & 74 & 426 & 16 & 18.877 & 1.2076 & 2.4691 \\
\hline 17 & Cottonwood Creek & 23-Oct-96 & 440 & 60 & 14 & 18.921 & 1.2100 & 2.4714 \\
\hline \multicolumn{9}{|c|}{ Sierra Nevada hydraulic Au-mining samples } \\
\hline & You Bet Pit & & N/A & N/A & 15 & 19.206 & 1.2255 & 2.4900 \\
\hline & Highway 80 \#1 & & N/A & N/A & 15 & 19.174 & 1.2240 & 2.4905 \\
\hline & Highway 80 \#2 & & N/A & N/A & 10 & 19.163 & 1.2245 & 2.4874 \\
\hline & Gold Run \#1 & & N/A & N/A & 22 & 19.129 & 1.2225 & 2.4848 \\
\hline & Gold Run \#2 & & N/A & N/A & 15 & 19.123 & 1.2213 & 2.4858 \\
\hline & Dutch Flat & & N/A & N/A & 16 & 19.323 & 1.2319 & 2.5005 \\
\hline & Malakoff Diggings \#1 & & N/A & N/A & 10 & 19.196 & 1.2246 & 2.4937 \\
\hline & Malakoff Diggings \#2 & & N/A & N/A & 8 & 19.484 & 1.2417 & 2.5161 \\
\hline & Creeks & & & & & & & \\
\hline & Steephollow Creek (at You Bet Pit) & & N/A & N/A & 14 & 19.093 & 1.2205 & 2.4858 \\
\hline & Greenhorn Creek & & N/A & N/A & 14 & 19.083 & 1.2201 & 2.4860 \\
\hline
\end{tabular}

the river between Bend Bridge (site \#6) and Verona (site \#9). Passing through Sacramento and further downstream the lead concentrations rose again to an average of $29 \mu \mathrm{g} /$ $\mathrm{g}(\mathrm{sd} \pm 6)$ (sites \#10 and \#11). The highest lead concentra- tion in suspended colloid material outside of the West Shasta $\mathrm{Cu}$-mining region occurred in sample 10, taken from Tower Bridge in Sacramento, downstream of the American River's confluence with the Sacramento River. 


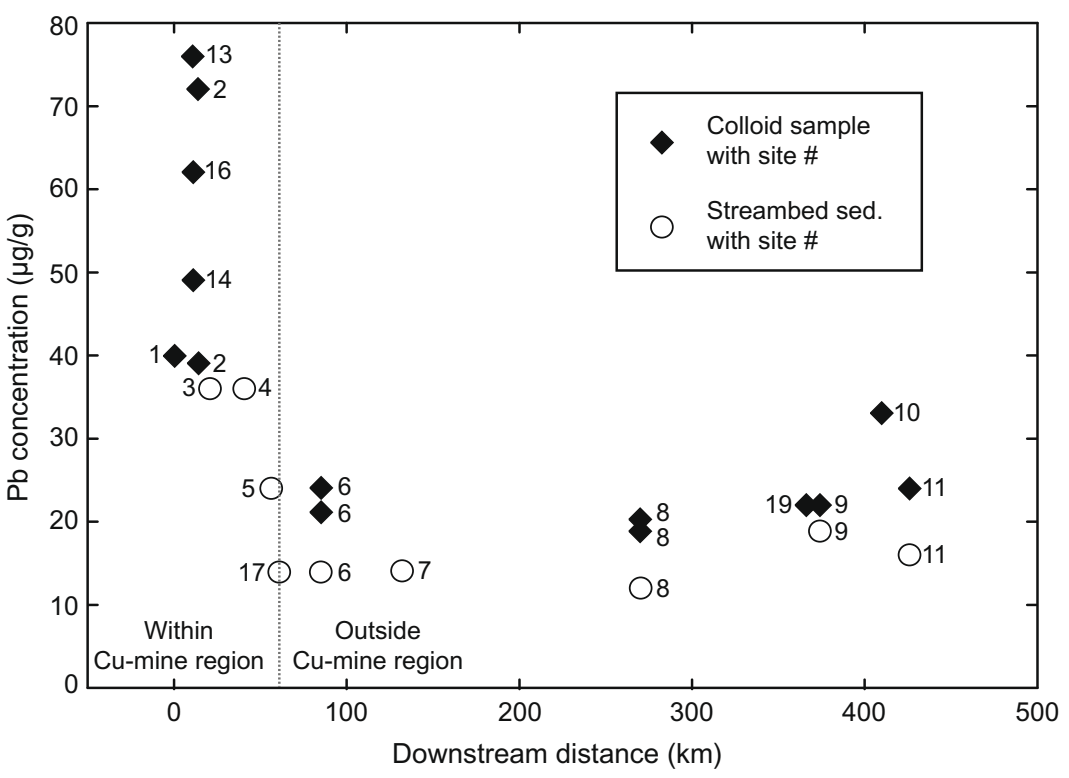

Fig. 2. Downstream variation in lead concentrations in samples of river water colloids and streambed sediment collected from the Sacramento River, its Spring Creek tributary in the West Shasta mining region, and the Yolo Bypass distributary. Colloid samples with identical sample numbers represent samples taken from the same location on different days (see Table 1).

\subsubsection{Sacramento River streambed sediments}

Lead concentrations of streambed sediments followed a pattern similar to that of the colloids. Samples collected within $60 \mathrm{~km}$ of the West Shasta Cu-mining region had an average lead concentration of $32 \mu \mathrm{g} / \mathrm{g}$ $(\mathrm{sd} \pm 7)$ whereas those collected at a distance of $60 \mathrm{~km}$ or greater had an average lead concentration of $15 \mu \mathrm{g} /$ $\mathrm{g}(\mathrm{sd} \pm 2)$. As was noted among colloid samples, the lead concentrations in samples collected in the vicinity of Sacramento and farther downstream were elevated (avg. $18 \mu \mathrm{g} / \mathrm{g}, \quad s d \pm 2$ ) compared to the other samples collected outside of the $\mathrm{Cu}$-mining region (avg. $14 \mu \mathrm{g} / \mathrm{g}$, $\mathrm{sd} \pm 1)$. The highest lead concentration among streambed sediments collected outside of the $\mathrm{Cu}$-mining region $(19 \mu \mathrm{g} / \mathrm{g})$ occurred in the sample taken at Verona (site \#9), where the Feather River joins the Sacramento River.

\subsubsection{Hydraulic Au-mining colloids and sediments}

The concentration of lead in sediment and water colloid samples from the hydraulic Au-mining region ranged from $8 \mu \mathrm{g} / \mathrm{g}$ in one sample from Malakoff Diggins to $22 \mu \mathrm{g} / \mathrm{g}$ in a sediment sample from Gold Run. The average lead concentration of sediments from the hydraulic Au-mining region was $14 \mu \mathrm{g} / \mathrm{g}(\mathrm{sd} \pm 4)$, indistinguishable from the average lead concentration of Sacramento River streambed sediments collected from outside of the West Shasta Cu-mining region $(15 \mu \mathrm{g} / \mathrm{g}$, sd \pm 2 ).

\subsection{Lead Isotopic compositions}

Lead isotopic variations among colloid and streambed sediment samples parallel the patterns seen in lead concentrations (Fig. 3a and b).

\subsubsection{Colloids within the Cu-mining district}

Colloid samples collected within $15 \mathrm{~km}$ of the $\mathrm{Cu}-\mathrm{min}$ ing region form a co-linear array in a plot of ${ }^{206} \mathrm{~Pb} /{ }^{207} \mathrm{~Pb}$ vs. ${ }^{208} \mathrm{~Pb} /{ }^{207} \mathrm{~Pb}$ and contain the lowest isotopic ratios among the samples in this study. The lowest ratios $\left({ }^{206} \mathrm{~Pb} /{ }^{207} \mathrm{~Pb}=1.1657\right.$ and $\left.{ }^{208} \mathrm{~Pb} /{ }^{207} \mathrm{~Pb}=2.4277\right)$ are found in Spring Creek as it enters Keswick Reservoir (site \#14). Upstream of the Spring Creek sample site is Iron Mountain, the largest of the historical copper mines in the West Shasta mining district. The highest isotopic values among samples in the $\mathrm{Cu}$-mining region $\left({ }^{206} \mathrm{~Pb} /{ }^{207} \mathrm{~Pb}=1.1967\right.$ and $\left.{ }^{208} \mathrm{~Pb} /{ }^{207} \mathrm{~Pb}=2.4444\right)$ occurred in the farthest upstream sample in the study (site \#1), taken on the Sacramento River below Shasta Dam. Lake Shasta receives streams draining several smaller copper-zinc mines of the West Shasta Cu-mining district, as well as copper-zinc mines of the East Shasta mining district. Two populations of mines can be distinguished isotopically, those of Iron Mountain and those upstream of Shasta Dam.

\subsubsection{Colloids outside of the Cu-mining district}

Colloid samples collected farther than $60 \mathrm{~km}$ downstream from the $\mathrm{Cu}$-mining region plot in a narrow range of isotopic compositions $\left({ }^{206} \mathrm{~Pb} /{ }^{207} \mathrm{~Pb}=1.204-1.210\right.$ and ${ }^{208} \mathrm{~Pb} /{ }^{207} \mathrm{~Pb}=2.464-2.472$; Fig. 3a and b). One colloid sample (site \#10) outside of the $\mathrm{Cu}$-mining region plots apart from the rest, having the highest isotope ratios in the study $\left({ }^{206} \mathrm{~Pb} /{ }^{207} \mathrm{~Pb}=1.2176\right.$ and $\left.{ }^{208} \mathrm{~Pb} /{ }^{207} \mathrm{~Pb}=2.4985\right)$. This sample was taken from Tower Bridge, Sacramento, just downstream of the entry of American River into the Sacramento River. As previously noted, this sample also contains the highest lead concentration found in any sample outside of the $\mathrm{Cu}$-mining region.

When viewed in detail, the colloid samples collected from outside of the $\mathrm{Cu}$-mining region fall into to two sub- 

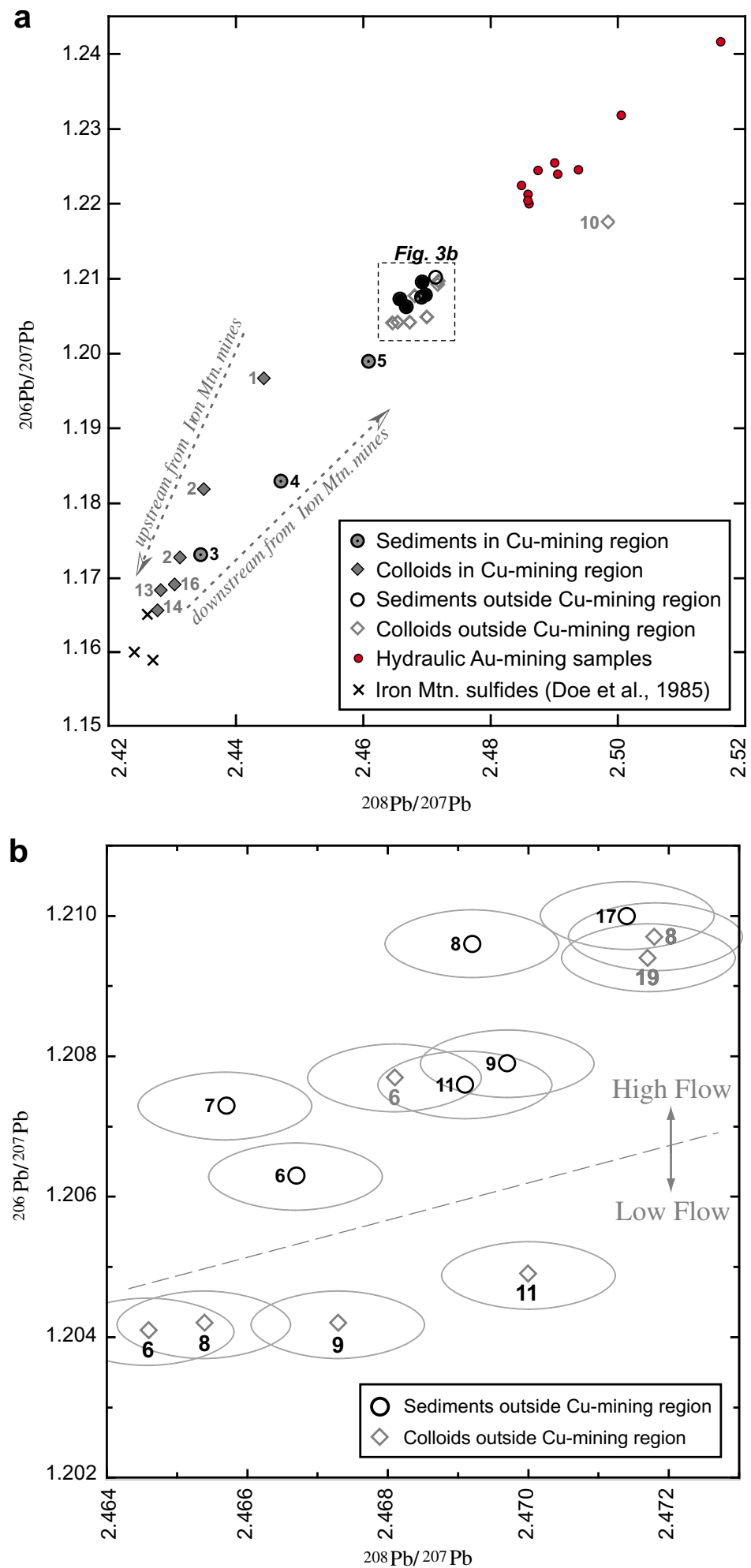

Fig. 3. (a) Lead isotope ratio plot of colloid samples and streambed sediment samples from within the West Shasta mining region, and colloid samples and streambed sediment samples from outside of the West Shasta mining region. Samples in the dashed box are shown in detail in (b). (b) Lead isotope ratio plot of samples enclosed by the dashed box in (a) streambed sediments and colloids from outside of the West Shasta mining region. Ellipses indicate external precision on analysis of $0.05 \%$ for ${ }^{208} \mathrm{~Pb} /{ }^{207} \mathrm{~Pb}$ and $0.04 \%$ for ${ }^{206} \mathrm{~Pb} /{ }^{207} \mathrm{~Pb}$.

groups: (i) samples taken in December 1996 fall on a co-linear trend with lower ${ }^{206} \mathrm{~Pb} /{ }^{207} \mathrm{~Pb}$ isotopic values than (ii) a second co-linear trend of samples taken in January 1997

(Fig. 3b and Table 1). At two locations (sites \#6 and \#8) 
samples were taken both in December 1996 and January 1997 and show the same offset as seen in the samples as a whole. The discharge measured at three gauging stations on the Sacramento River was an average of $42 \%$ higher on the days sampled in January 1997 compared with those sampled in December 1996 (Fig. 4).

\subsubsection{Sacramento River and cottonwood creek streambed sediments}

The variation in lead isotopic compositions from streambed sediments can also be described with reference to their distance downstream from the West Shasta $\mathrm{Cu}-$ mining district. The isotopic compositions of the three streambed sediments collected within $60 \mathrm{~km}$ of the $\mathrm{Cu}-\mathrm{min}-$ ing region (sites \#3, \#4, and \#5) follow a co-linear trend from low isotopic compositions in the sample taken nearest the $\mathrm{Cu}$-mining region $\left({ }^{206} \mathrm{~Pb} /{ }^{207} \mathrm{~Pb}=1.1732\right.$ and ${ }^{208} \mathrm{~Pb} /$ $\left.{ }^{207} \mathrm{~Pb}=2.4344\right)$ to an isotopic composition approaching the samples collected outside of the $\mathrm{Cu}$-mining region (Fig. 3a). Isotopic compositions of the streambed sediments collected $>60 \mathrm{~km}$ from the $\mathrm{Cu}$-mining region fall within the cluster of colloid samples also collected outside of the $\mathrm{Cu}$ mining region. In addition, the isotopic ratios of the streambed sediments follow the same co-linear trend as those of the colloids collected during the higher discharge period in January 1997.

\subsubsection{Streambed sediment and colloid samples compared}

At sample sites where both streambed sediments and river water colloids were collected, the lead isotopic values of the sediment/colloid pairs do not correspond to each other (Fig. 3b). At sites \#6, \#8, and \#9 the colloids collected during December 1996 have lower lead isotope ratios than their associated streambed sediments, whereas colloids collected during January 1997 have higher lead isotope ratios than their associated streambed sediments. Such decoupling suggests that local streambed sediment is not the predominant source of lead to river colloids.

\subsubsection{Hydraulic Au-mining sediment samples}

The ten samples taken from the hydraulic gold mining regions in the Yuba and Bear river drainage basins (Fig. 1) fall into two groups (Fig. 3a). The first group contains eight samples that cluster around a range of lead isotope compositions: ${ }^{206} \mathrm{~Pb} /{ }^{207} \mathrm{~Pb}=1.2213-1.2255$ and ${ }^{208} \mathrm{~Pb} /{ }^{207} \mathrm{~Pb}=2.4848-2.4937$. For the purpose of discussion below, this group is designated as the low-ratio hydraulic Au-mining samples.

The second group contains two samples, one from Malakoff Diggins (site of the largest hydraulic mine) and the second from a smaller hydraulic mine at Dutch Flat. Compared to the other hydraulic Au-mining samples, these two samples have distinctly higher ${ }^{206} \mathrm{~Pb} /{ }^{207} \mathrm{~Pb}$ and ${ }^{208} \mathrm{~Pb} /{ }^{207} \mathrm{~Pb}$ ratios. For the purpose of discussion below, these two samples are designated as the high-ratio hydraulic Au-mining samples.

\section{DISCUSSION}

\subsection{Lead concentration variations in colloid samples}

Changes in lead concentrations of colloid samples reflect dynamic processes in the riparian system. The colloidal component sampled carries approximately $80 \%$ of the lead found in the Sacramento River water. Because colloids can be advected into the river by surface runoff, re-suspended

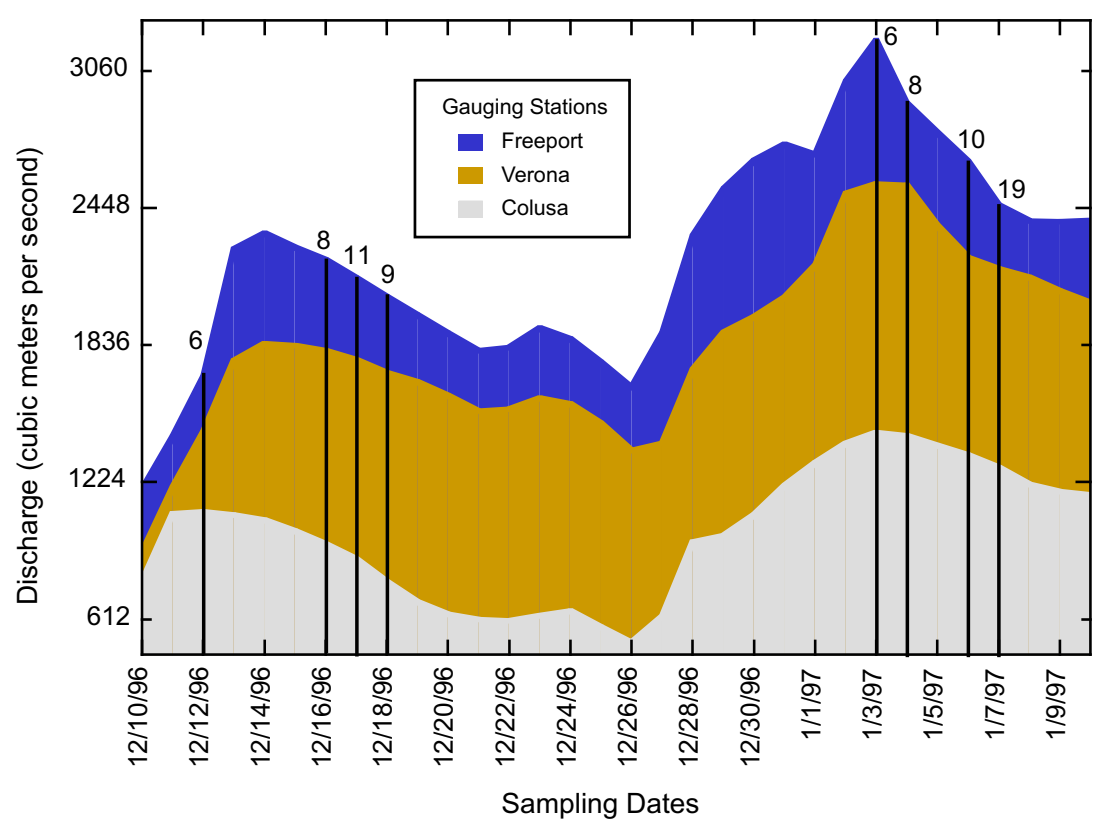

Fig. 4. Sacramento River discharge measured at three gauging stations during the sampling period. The dates of colloid sample collection are marked by vertical lines: 6. above Bend Bridge; 8. at Colusa; 9. at Verona; 10. at Tower Bridge; 11. at Freeport; and 19. Yolo Bypass at I-80 near W. Sacramento. Also see Fig. 1 for sample locations. Discharge data were obtained from the California Department of Water Resources California Data Exchange Center (http://cdec.water.ca.gov/). 
into river water from streambed sediments, and after aggregation settled out of the water by physical processes they provide a sensitive tool for tracing the movement of lead into and out of reservoirs that control lead flux in the Sacramento River.

The constant-rate settling of lead bound to suspended particles such as colloids should produce an exponential decrease in lead concentrations downriver of the point where lead is introduced. This idealized non-conservative trace element behavior can be expressed by a simple decay law equation with a term added to allow for an additional downstream contribution of lead to the water column from internal (e.g., streambed) and external (e.g., runoff) sources (Thomann and Mueller, 1987):

$C=C_{0} * \mathrm{e}^{(-K * x)}+I_{\mathrm{s}}$

where

$C_{0}=$ initial concentration of lead (i.e., at $x=0$ ),

$C=$ concentration of the element at downstream distance $x$,

$X=$ downstream distance (in $\mathrm{km}$ from the first sample point where lead is introduced),

$K=$ lead-loss constant (units of $1 / \mathrm{km}$ ),

$I_{\mathrm{s}}=$ concentration of lead supplied by internal sources.

The decay law equation adequately models the change in lead concentrations in Sacramento River water colloids from the $\mathrm{Cu}$-mining region to $370 \mathrm{~km}$ downstream at Verona (sample 9; Fig. 5). The 4-fold reduction of lead concentrations within $14 \mathrm{~km}$ of the $\mathrm{Cu}$-mining region is consistent with, and in fact predicted by, the settling out of lead scavenged to particles. However, in order to maintain the concentrations of lead measured in colloids downstream of the $\mathrm{Cu}$-mining region, an additional source providing $19 \mu \mathrm{g} / \mathrm{g}$ of lead to river water colloids is required $\left(I_{\mathrm{s}}=19\right)$. Without such a source, the rate of lead loss in the river predicted by

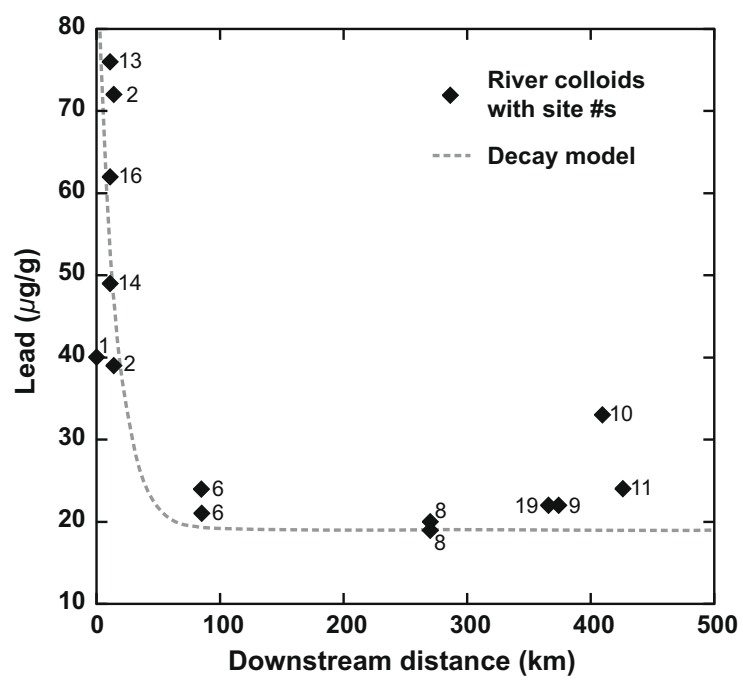

Fig. 5. Concentration variation in colloid samples showing the trend of an exponential decay model for lead loss during downstream transport. See Section 5 for details. the model would reduce the lead concentration to nearly zero within $20 \mathrm{~km}$ of the $\mathrm{Cu}$-mining district. The source of the additional lead is not constrained by the concentration data or by the model but is likely to be either streambed sediments or surface runoff because point source discharges or additional inputs from acid mine drainage are not present along the $200 \mathrm{~km}$ stretch of the Sacramento River between Bend Bridge (site \#6) and Colusa (site \#8).

The simple decay law model does not adequately explain the lead concentrations observed at Verona and farther downstream ( site \#8). The model predicts that lead concentrations along the Sacramento River will decrease from the value of $20 \mu \mathrm{g} / \mathrm{g}$ measured at Colusa to $19 \mu \mathrm{g} / \mathrm{g}$ at Verona (site \#9). At Verona, where the Feather River enters the Sacramento River, the measured concentration is $16 \%$ higher than the modeled value. The lead concentration measured from the Yolo Bypass, which receives water from the Sacramento River near Verona, is also 16\% higher than the predicted value. Farther downstream, at Tower Bridge, past the point where the American River enters the Sacramento River, the measured valued is $74 \%$ higher than the model predicts. And at Freeport, the site farthest downriver in the study, the measured colloidal lead concentration is $26 \%$ greater than the modeled value. These increases suggest downriver lead inputs in addition to the $19 \mu \mathrm{g} / \mathrm{g}$ lead flux used in the model.

It appears, therefore, that there are three stages of change in lead concentration along the Sacramento River: (i) the first stage is within $14 \mathrm{~km}$ of the $\mathrm{Cu}$-mining region where a 4-fold decrease in lead concentrations occurs, as predicted by the exponential decay law model due to particle settling; (ii) the second stage is the $360 \mathrm{~km}$ of Sacramento River between the $\mathrm{Cu}$-mining region and Verona along which colloidal lead concentrations approach an asymptotic limit, the result predicted by the decay law model with an internal source that contributes a $19 \mu \mathrm{g} / \mathrm{g}$ colloidal lead concentration; (iii) the third stage is the Sacramento River downstream of Verona where lead concentrations are $16-74 \%$ higher than the modeled values. Lead isotopic compositions allow identification of the lead sources that create these concentration variations.

\subsection{Lead isotope variations in $\mathrm{Cu}$-mining region colloids}

Isotopic compositions of colloid samples collected within the $\mathrm{Cu}$-mining region fall along an array defined by a binary mixture of lead from the Lake Shasta and Iron Mountain mining sources (Figs. 1 and 3a). Ratios of colloids collected from below Lake Shasta Dam (site \#1; ${ }^{206} \mathrm{~Pb} /{ }^{207} \mathrm{~Pb}=1.1967$ and $\left.{ }^{208} \mathrm{~Pb} /{ }^{207} \mathrm{~Pb}=2.4444\right)$ are inferred to represent the lead isotope compositions of acid mine drainage into Lake Shasta mixed with a minor component of lead derived from weathering of rocks in the Lake Shasta drainage. The lead isotope composition $\left({ }^{206} \mathrm{~Pb} /{ }^{207} \mathrm{~Pb}=1.1657-1.1692\right.$ and ${ }^{208} \mathrm{~Pb} /{ }^{207} \mathrm{~Pb}=2.277-$ 2.4304) of samples collected from Spring Creek (sites \#13, \#14, and \#16) contain lead derived from the Iron Mountain mining district that drains into Spring Creek. Spring Creek empties into Keswick Reservoir downstream of sample site \#1. The isotopic composition $\left({ }^{206} \mathrm{~Pb} /{ }^{207} \mathrm{~Pb}=1.1728-1.1819\right.$ 
and $\left.{ }^{208} \mathrm{~Pb} /{ }^{207} \mathrm{~Pb}=2.4312-2.4350\right)$ of lead from the site farthest downstream among the $\mathrm{Cu}$-mining region samples (site \#2) represents a mixture in Keswick Reservoir of lead from the Lake Shasta mines with lead from the Iron Mountain mines. Because river discharge varied on the dates that site \#2 was sampled, the isotopic compositions vary in the two samples from site \#2.

Taking the ${ }^{206} \mathrm{~Pb} /{ }^{207} \mathrm{~Pb}$ compositions from Spring Creek (site \#14) in January 1997 and Lake Shasta (site \#1) in December 1996 as mixing end-members, the sample taken from Keswick Reservoir (site \#2) in December 1996 contains 23\% Lake Shasta component and 77\% Iron Mountain component, whereas the sample taken in January 1997 contains 53\% Lake Shasta component and 47\% Iron Mountain component. The higher precipitation, and its accompanying increase in river discharge in January 1997 (Fig. 4), appears to have carried a greater portion of Lake Shasta mining lead into Keswick Reservoir compared to the 43\% lower discharge period observed in December 1996.

\subsection{Lead isotope variations in $\mathrm{Cu}-\mathrm{mining}$ region streambed sediments}

The three streambed sediments collected within the $\mathrm{Cu}-$ mining region fall along a linear trend $\left(R^{2}=0.99\right.$, leastsquares linear regression) extending from the lead isotope compositions of the Iron Mountain $\mathrm{Cu}$-mines towards the composition of pre-anthropogenic terrestrial lead (Fig. 6).
This linear array in such a plot of lead isotope ratios is consistent with binary mixing of two lead sources.

However, three potential sources are co-linear in this case. These are the Iron Mountain Cu-mines $\left({ }^{206} \mathrm{~Pb} /\right.$ ${ }^{207} \mathrm{~Pb}=1.166$ and ${ }^{208} \mathrm{~Pb} /{ }^{207} \mathrm{~Pb}=2.428$, as observed at site \#14), the average lead isotope composition of leaded gasoline from 1964 to $1979\left({ }^{206} \mathrm{~Pb} /{ }^{207} \mathrm{~Pb}=1.183\right.$ and ${ }^{208} \mathrm{~Pb} /$ ${ }^{207} \mathrm{~Pb}=2.443$ ), and the pre-anthropogenic terrestrial lead measured in sediment cores from San Francisco Bay radiometrically dated to before $1853 \mathrm{AD}\left(\left({ }^{206} \mathrm{~Pb} /{ }^{207} \mathrm{~Pb}=1.215\right.\right.$ 1.225 and $\left.{ }^{208} \mathrm{~Pb} /{ }^{207} \mathrm{~Pb}=2.480-2.488\right)$. This overlap precludes distinguishing between the mingled influences of $\mathrm{Cu}$-mining and gasoline lead, but the linear trend towards the pre-anthropogenic terrestrial values confirms the presence of a terrestrial lead contribution, as one would expect to find in whole sediment digests.

\subsection{Lead isotope variations in samples collected outside of the $\mathrm{Cu}$-mining region}

Isotopic compositions of samples of colloids and streambed sediments collected outside of the $\mathrm{Cu}$-mining region illuminate the dynamics of lead in the Sacramento River in the $370 \mathrm{~km}$ reach of the river along which they were collected. The isotopic compositions of the colloids and those of the streambed sediments are each consistent in their indication of the binary mixing of lead sources outside of the $\mathrm{Cu}$-mining region.

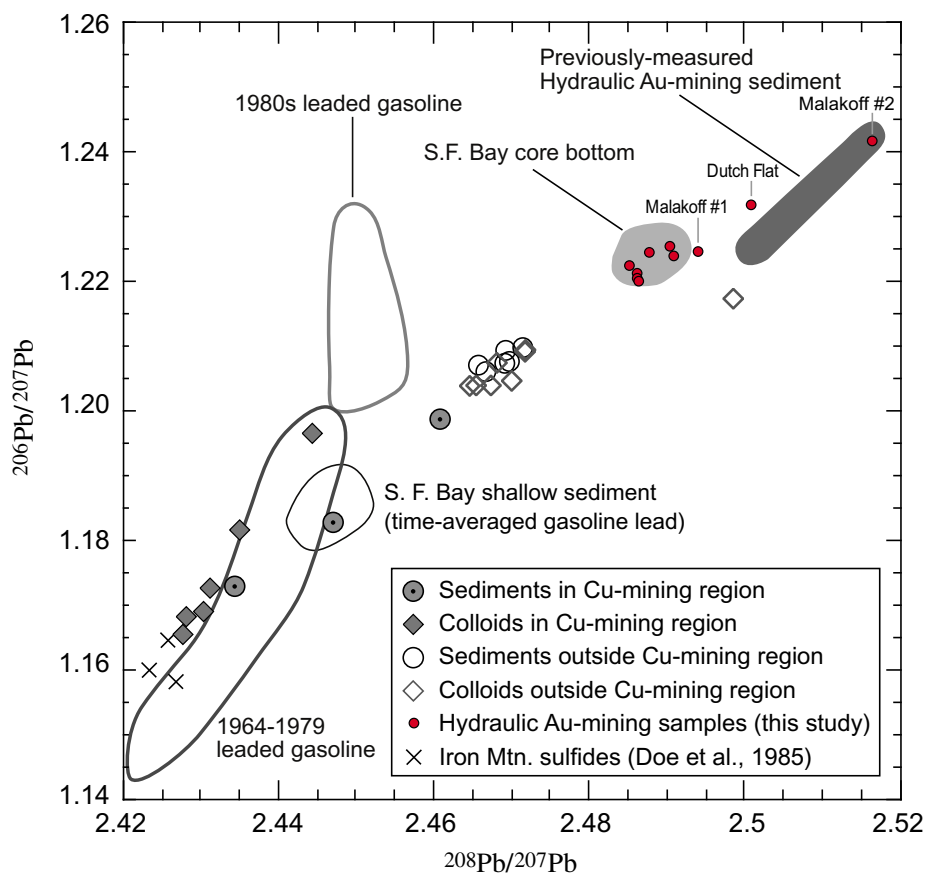

Fig. 6. Comparison of lead isotope compositions of samples in this study with contaminant sources identified in previous studies. San Francisco Bay core bottom sediments are equivalent to the pre-anthropogenic isotopic composition of Sacramento River deposits into San Francisco Bay (Ritson et al., 1999). The field for hydraulic Au-mining sediment signatures represent sediments advected into the river system from Sierra Nevada placer gold mining beginning in the late 19th century (Dunlap et al., 2000; Steding et al., 2000). Leaded gasoline isotopic compositions are shown for gasoline sold and used in California during the indicated time periods (Dunlap et al., 2000; Steding et al., 2000, and references therein). 


\subsubsection{Identifying lead sources}

As noted in Section 4, the colloid samples fall into high flow and low flow subgroups (Fig. 3b): these subgroups plot in trends that parallel those seen in previous research (Steding et al., 2000) at the mouth of the Sacramento River (Fig. 7). In that study the authors observed that samples collected during periods of relatively higher river discharge were displaced towards higher $\left({ }^{206} \mathrm{~Pb} /{ }^{207} \mathrm{~Pb}\right.$ values $(\leqslant 1.205)$ relative to the values in samples collected during periods of lower flow $\left({ }^{206} \mathrm{~Pb} /{ }^{207} \mathrm{~Pb} \leqslant 1.200\right)$. This variation was attributed to a mixture of three lead sources: time-averaged 1960-70s leaded gasoline emissions bound in bed sediments $\left({ }^{206} \mathrm{~Pb} /{ }^{207} \mathrm{~Pb}=1.183\right.$ and $\left.{ }^{208} \mathrm{~Pb} /{ }^{207} \mathrm{~Pb}=2.443\right), \quad 1980 \mathrm{~s}$ leaded gasoline emissions bound in the uppermost soil layers of the drainage basin $\left({ }^{206} \mathrm{~Pb} /{ }^{207} \mathrm{~Pb}=1.200-1.234\right.$ and ${ }^{208} \mathrm{~Pb} /{ }^{207} \mathrm{~Pb}=2.442-2.457$ ), and lead from historic hydraulic Au-mining sediments $\left({ }^{206} \mathrm{~Pb} /{ }^{207} \mathrm{~Pb}=1.223-1.245\right.$ and $\left.{ }^{208} \mathrm{~Pb} /{ }^{207} \mathrm{~Pb}=2.497-2.517\right)$. Periods of elevated surface runoff were interpreted to advect additional 1980s gasoline lead from soils into the river, producing the elevated lead isotopes values seen during high-flow periods. By contrast, the water samples collected during low-flow periods were interpreted to be dominated by lead from the hydraulic Au-mining sediments and time-averaged 1960-70s gasoline emissions.

Whereas the former study referenced above was unable to distinguish between lead in hydraulic Au-mining sediments that was re-suspended from within the delta and hydraulic Au-mining sediments (or their colloidally bound lead) newly advected out of the Sierra Nevada foothills, data in the present study clearly demonstrate the presence of hydraulic Au-mining sediments in the Sacramento River upstream of its delta.

A component of lead derived from hydraulic Au-mining sediments is inferred from the linear mixing trends in Sacramento River sediment and colloid samples collected in this study. Isotopic compositions of sediments and colloids collected in the Sacramento River outside of the $\mathrm{Cu}$-mining region each define a linear mixing trend between past leaded gasoline emissions and the high-ratio hydraulic Au-mining sediment (Fig. 8). To illustrate this mixing trend, a least-squares linear regression through the colloid samples $\left(R^{2}=0.88 ; m=0.40 ; F=44 ; \mathrm{df}=6\right.$; $n=8$ ) can be calculated, extending from the field of gasoline lead compositions towards values of high-ratio hydraulic Au-mining sediments; a linear regression through the streambed sediment data $\left(R^{2}=0.38 ; m=\right.$ $0.42 ; F=1.7 ; \mathrm{df}=3 ; n=5$ ) follows a trend of nearly identical slope. This second linear regression through the sediment samples does not have a high statistical significance when considered in isolation. However, when considered in conjunction with the linear regression of the colloid samples, the trends corroborate upstream what was seen downstream, at the Sacramento River mouth, in two previous studies (Dunlap et al., 2000; Steding et al., 2000).

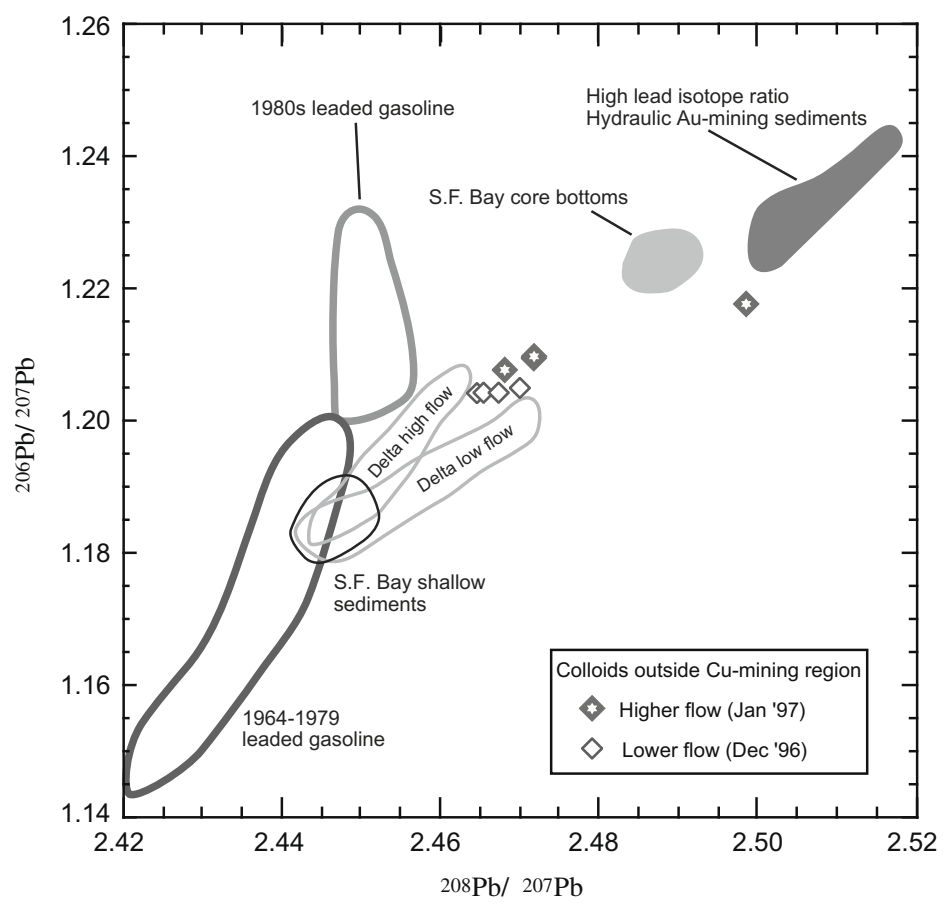

Fig. 7. Isotope plot of colloids outside of the mining region, distinguishing between those sampled during relatively higher flow in January 1997 and lower flow in December 1996. The field shown here for high lead isotope ratio hydraulic Au-mine sediments encompasses data from previous studies (see Fig. 6) and the two high-ratio hydraulic Au-mine sediments analyzed in this study. The field for San Francisco Bay shallow sediments is attributed to the accumulation of past leaded gasoline emissions in the Bay (Ritson et al., 1999). The field for delta high flow encloses unfiltered Sacramento River waters sampled from 1992 to 1995 (Steding et al., 2000; also see Background section). The field for delta low flow encloses unfiltered Sacramento River waters sampled from 1993 to 1998 (Steding et al., 2000; also see Background section). Sources for the data in the fields for leaded gasoline and San Francisco Bay core bottoms are given in the caption to Fig. 6. 


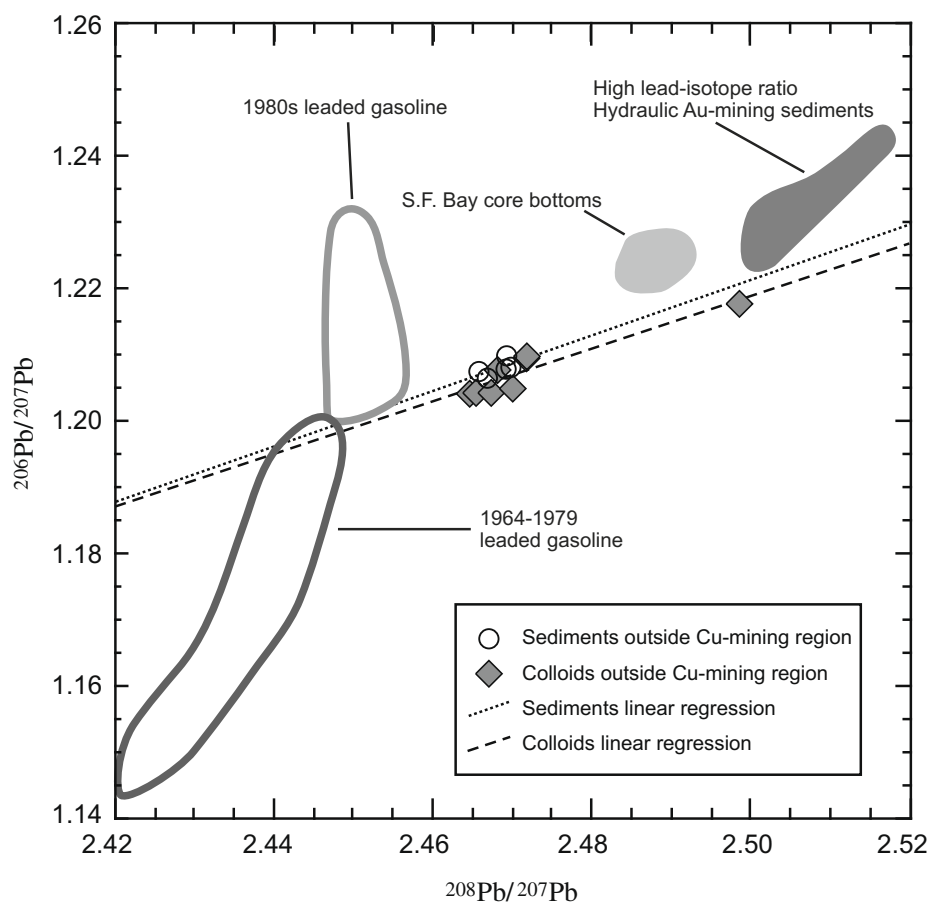

Fig. 8. Binary mixing trends in samples outside the mining region. The dashed lines represent two least-squares linear regressions, one through the colloid samples (long dash; $R^{2}=0.88$ ) and the second though streambed sediments (short dash; $R^{2}=0.38$ ). Other fields as in Fig. 7.

The linear regression through the colloid samples is controlled by the isotopic value of one sample taken at Tower Bridge (\#10). This sample is located at a point on the Sacramento River downstream of the confluence with the American and Feather rivers, approximately $160 \mathrm{~km}$ downstream from the largest historical hydraulic Au-mines. The presence of a lead isotope composition, such as that in the Tower Bridge sample, that is intermediate between that of the other Sacramento River colloids and the measured composition of hydraulic Au-mining sediments supports the conclusion that the hydraulic Au-mining sediments are a mixing end-member in the Sacramento River. The fact that the Tower Bridge (\#10) sample was collected during a period of high river discharge is interpreted to indicate that a component of high-ratio hydraulic Au-mining sediment was re-suspended from riverbed sediments or advected from drainage basin soils, accounting for the higher lead isotope ratio of the sample.

Lead from the high-ratio hydraulic Au-mining sediment is the best explanation for the linear trend away from gasoline values seen in colloids and Sacramento riverbed sediment samples. A field of lead isotope compositions derived from hydraulic Au-mining sediments was first defined in a previous study (Fig. 6; Dunlap et al., 2000) by direct analysis of sediments from the Malakoff Diggins $\left({ }^{206} \mathrm{~Pb} /{ }^{207} \mathrm{~Pb}=1.2250-1.2417\right.$ and ${ }^{208} \mathrm{~Pb} /{ }^{207} \mathrm{~Pb}=2.5013$ 2.5161 ), the largest of the historical hydraulic Au-mining operations, located on the Yuba River (Fig. 1). The highratio hydraulic Au-mine sediments in this study confirm and slightly extend the field first defined by Dunlap et al., 2000 (Figs. 7 and 8). In fact, the linear regression through the colloid samples appears to indicate that some hydraulic
Au-mining sediments may have lower ${ }^{206} \mathrm{~Pb} /{ }^{207} \mathrm{~Pb}$ than has been directly measured.

The high-ratio hydraulic Au-mining sediment is interpreted to represent the dominant hydraulic Au-mining contribution to the Sacramento River because samples from the largest hydraulic mine at Malakoff Diggins primarily fall within this field and because an increase in lead isotope ratios above pre-anthropogenic values is in fact observed in San Francisco Bay sediment cores at the onset of hydraulic Au-mining (Dunlap et al., 2000).

The low-ratio hydraulic Au-mining sediments measured in this study have lead isotope ratios indistinguishable from those of the sediments in pre-anthropogenic San Francisco Bay core bottoms. This confirms that the sediments in the pre-anthropogenic core bottoms are consistent in lead isotope composition with sediments of the Sierra Nevada foothills, strengthening the interpretation in previous studies that the pre-anthropogenic core bottoms record the prevailing pre-anthropogenic lead isotope composition of the sediment load in the Sacramento River.

Hydraulic Au-mining also occurred in the American River basin, and the isotopic composition of a colloid sample from Tower Bridge (site \#10; ${ }^{206} \mathrm{~Pb} /{ }^{207} \mathrm{~Pb}=1.2176$ and $\left.{ }^{208} \mathrm{~Pb} /{ }^{207} \mathrm{~Pb}=2.4985\right)$, taken from below the confluence of the American River with the Sacramento River, is interpreted to record the influence of hydraulic Au-mining deposits in the American River basin, the first indication of that signature.

\subsubsection{Quantifying mixing proportions}

Using the lead isotopic data in this study, the proportions of gasoline lead and high-ratio hydraulic Au-mining 
lead contributing to the lead isotope composition of Sacramento River colloids outside of the $\mathrm{Cu}$-mining region was calculated. A mixing line can be constructed extending from the average lead isotope composition of high-ratio hydraulic Au-mining sediment $\left({ }^{206} \mathrm{~Pb} /{ }^{207} \mathrm{~Pb}=1.235\right.$ and $\left.{ }^{208} \mathrm{~Pb} /{ }^{207} \mathrm{~Pb}=2.509\right)$ through the average isotopic composition of river water colloids $\left({ }^{206} \mathrm{~Pb} /{ }^{207} \mathrm{~Pb}=1.206\right.$ and $\left.{ }^{208} \mathrm{~Pb} /{ }^{207} \mathrm{~Pb}=2.468\right)$. Such a mixing line intersects the field of gasoline lead isotope ratios over a range of values $\left({ }^{206} \mathrm{~Pb} /{ }^{207} \mathrm{~Pb}=1.185-1.194\right.$ and ${ }^{208} \mathrm{~Pb} /{ }^{207} \mathrm{~Pb}=2.437-$ 2.448 ), resulting in a calculated contribution of $57-67 \%$ gasoline lead and 43-33\% high-ratio hydraulic Au-mining lead to the lead in river water colloids. This result is consistent with previous estimates based on samples of Sacramento River water collected at its inflow to San Francisco Bay estuary (Dunlap et al., 2000; Steding et al., 2000). This independent corroboration of those estimates demonstrates that lead from past gasoline emissions is the dominant component of lead in the Sacramento River along the $415 \mathrm{~km}$ reach of the river from Bend Bridge (site \#6) to San Francisco Bay-Delta estuary. Furthermore, the contribution of lead from high-ratio hydraulic Au-mining sediments is evidenced along $126 \mathrm{~km}$ of the river from Verona to San Francisco Bay, a reach defined by the entry of the first river (the Feather River) carrying hydraulic Au-mining sediment into the Sacramento River system.

\section{CONCLUSIONS}

The lead isotopic data presented in this study demonstrate that the present-day flux of lead in the Sacramento River system is dominated by the admixture of historical industrial lead sources. The water flowing in the Sacramento River below Keswick Dam is influenced by metal sources at Iron Mountain and other, isotopically distinct, $\mathrm{Cu}$-mine inputs upstream of Shasta Dam. The influence of lead from the $\mathrm{Cu}$-mine drainage upstream of Keswick Dam is confined to a $60 \mathrm{~km}$ reach of the river extending to just downstream of Keswick Reservoir due to the removal of lead by particle settling. Bed sediments and suspended colloids collected in the $\mathrm{Cu}$-mining region exhibit a trend towards pre-anthropogenic terrestrial lead compositions, whereas sediment and colloid samples collected from outside of the $\mathrm{Cu}$-mining region define a binary mixing trend between high-ratio hydraulic Au-mining lead and past leaded gasoline emissions. These two sources dominate lead inputs to the Sacramento River outside of the $\mathrm{Cu}$-mining region, confirming previous studies that identified hydraulic Au-mining and leaded gasoline lead (but not West Shasta $\mathrm{Cu}$-mining district lead) in dated rivermouth sediment cores.

This study estimates that, outside of the Cu-mining region, $57-67 \%$ of the lead in the Sacramento River is derived from past gasoline emissions whereas $33-43 \%$ is derived from hydraulic Au-mining sediment. This estimate from upstream data is in agreement with previous estimates made from the isotopic compositions of water samples from the Sacramento/San Joaquin River delta (Dunlap et al., 2000; Steding et al., 2000), and this study is the first to directly measure the dominance of lead from past gasoline emissions throughout a large $\left(>160,000 \mathrm{~km}^{2}\right)$ riparian system.
Furthermore, the data show that the flow into the Sacramento River of lead from high-ratio hydraulic Aumining sediment and sediments contaminated with lead from leaded gasoline is an ongoing process. Periods of high surface runoff and river discharge mobilize additional fluxes of lead from these two contaminant lead sources and carry them into the river. These pulses of lead driven by rainfall events suggest a direct link can exist between local climate change and the transport of toxic metals in surface waters.

Finally, the pattern and controls on lead movement in the Sacramento River provide direct insight into the origin, fate, and transport of other contaminant metals that can travel with sediments in the system. Mercury, for example, was commonly used to extract gold from hydraulic Aumining in the Sierra Nevada (Alpers et al., 2005), and mercury concentrations correlate closely with lead in recently deposited sediments in Englebright Lake, a reservoir on the Yuba River that was the site of extensive historical gold mining activity (Alpers et al., 2006). Deposits of sediment with elevated mercury concentrations accumulated in the San Francisco Bay-Delta estuary after having been washed down the Sacramento River with hydraulic Au-mining sediments in the past (e.g., Hornberger et al., 1999; Roth et al., 2001). It is clear from this study that lead and other contaminants such as mercury, representing legacy anthropogenic sources, continue to enter the Sacramento River from its Sierra Nevada tributaries.

\section{ACKNOWLEDGMENTS}

The authors thank Stanley Church, Richard Tosdal, and three anonymous reviewers for their insightful and constructive reviews of this paper. We also gratefully acknowledge financial support from the Sacramento Regional County Sanitation District and from the Sarkis Acopian Endowment to the American University of Armenia.

\section{REFERENCES}

Alpers C. N., Antweiloper R. A., Taylor H. E., Dileanis P. D. and Domagalski J. L. (2000b) Metals transport in the Sacramento River, California, 1996-97: vol. 2. Interpretation of metal loads. US Geological Survey Water-Resources Investigations Report 00-4002, 106 p. Available from: http://pubs.usgs.gov/wri/ wrir00-4002/.

Alpers C. N., Hunerlach M. P., Marvin-DiPasquale M. C., Antweiler R. C., Lasorsa B. K., De Wild J. F. and Snyder, N. P. (2006) Geochemical data for mercury, methylmercury, and other constituents in sediments from Englebright Lake, California, 2002. US Geological Survey Data Series 151, 95 p. Available from: http://pubs.water.usgs.gov/ds151/.

Alpers C. N., Hunerlach M. P., May J. T. and Hothem R. L. (2005) Mercury contamination from historical gold mining in California. US Geological Survey Fact Sheet 2005-3014, 6 p. Available from: http://water.usgs.gov/pubs/fs/2005/3014/.

Alpers C. N., Nordstrom D. K. and Spitzley J. (2003) Extreme acid mine drainage from a pyritic massive sulfide deposit: the Iron Mountain end-member. In Environmental Aspects of Mine Wastes. Mineralogical Association of Canada Short-Course, vol. 31 (eds. J. L. Jambor, D. W. Blowes and A. I. M. Ritchie), pp. $407-430$. 
Alpers C. N., Taylor H. E. and Domagalski J. L. (eds.) (2000a) Metals transport in the Sacramento River, California, 19961997: vol 1. Methods and data. US Geological Survey WaterResources Investigations Report 99-4286, 430 p.

Chen J. H. and Tilton G. R. (1991) Applications of lead and strontium isotopic relationships to the petrogenesis of granitoid rocks, Central Sierra Nevada batholith, California. GSA Bull. 103, 439-447.

Church S. E., Alpers C. N., Vaughn R. B., Briggs P. H. and Slotton D. G. (1999) Use of lead isotopes as natural tracers of metal contamination - a case study of the Penn Mine and Camanche Reservoir, California. In The Environmental Geochemistry of Mineral Deposits, Part B: Case Studies and Research Topics, Reviews in Economic Geology, vol. 6B (eds. L. H. Filipek and G. S. Plumlee), pp. 567-583.

Church S. E., Unruh D. M., Fey D. L. and Sole T. C. (2004) Trace elements and lead isotopes in streambed sediment in streams affected by historical mining. In Integrated Investigations of Environmental Effects of Historical Mining in the Basin and Boulder Mining Districts, Boulder River watershed, Jefferson County, Montana: US Geological Survey Professional Paper 1652 (eds. D. A. Nimick, S. E. Church and S. E. Finger), pp. 279-336, Chap. D8. Available from: http://pubs.usgs.gov/pp/ 2004/1652/.

Church S. E., von Guerard P. and Finger S. E. (eds.) (2007) Integrated investigations of environmental effects of historical mining in the Animas River watershed, San Juan County, Colorado. US Geological Survey Professional Paper 1651, 1096 p, plus CD-ROM (in two volumes). Available from: http:// pubs.usgs.gov/pp/1651/.

Church S. E., Wilson S. A., Vaughn R. B. and Fey D. L. (1994) Geochemical and lead-isotopic studies of river and lake sediments, upper Arkansas River drainage basin, Twin Lakes to Pueblo Reservoir, Colorado. US Geological Survey Open-File Report 94-412, 40 p.

Doe B. R., Delevaux M. H. and Albers J. P. (1985) The plumbotectonics of the West Shasta mining district, eastern Klamath Mountains, California. Econ. Geol. 80, 2136-2148.

Dunlap C. E., Bouse R. and Flegal A. R. (2000) Past leaded gasoline emissions as a non-point source tracer in riparian systems. Environ. Sci. Technol. 34(7), 1211-1215.

Flegal A. R. and Smith D. R. (1995) Measurements of environmental lead contamination and human exposure. Rev. Environ. Contam. Tox. 143, 1-45.

Hornberger M. I., Luoma S. N., van Geen A., Fuller C. and Anima R. (1999) Historical trends of metals in the sediments of San Francisco Bay, California. Mar. Chem. 64, 39-55.

Nichols F. H., Cloern J. E., Luoma S. N. and Peterson D. H. (1986) The modification of an estuary. Science 321, 567-573.
Nordstrom D. K. and Alpers C. N. (1999) Negative pH, efflorescent mineralogy, and consequences for environmental restoration at the Iron Mountain Superfund site, California. Proc. Natl. Acad. Sci. USA Colloquium Paper 96, 3455-3462.

Nordstrom D. K., Alpers C. N., Ptacek C. J. and Blowes D. W. (2000) Negative pH and extremely acidic mine waters from Iron Mountain, California. Environ. Sci. Technol. 34, 254-258.

Nriagu J. O. (1990) The rise and fall of leaded gasoline. Sci. Total Environ. 92, 13-28.

Nriagu J. O. and Pacyna J. M. (1988) Quantitative assessment of worldwide contamination of air, water and soils by trace metals. Nature 323, 134-139.

Patterson C. C. (1965) Contaminated and natural lead environments of man. Arch. Environ. Health 11, 344-360.

Patterson C. C., Settle D. and Glover B. (1976) Analysis of lead in polluted coastal seawater. Mar. Chem. 4(4), 305-319.

Ritson P., Bouse R., Flegal A. R. and Luoma S. N. (1999) Stable lead isotopic analyses of historic and contemporary lead contamination of San Francisco Bay estuary. Mar. Chem. 64, 71-83.

Roth D. A., Taylor H. E., Domagalski J., Dileais P., Peart D. B., Antweiler R. C. and Alpers C. N. (2001) Distribution of inorganic mercury in Sacramento River water and suspended colloidal sediment material. Arch. Environ. Contam. Toxicol. 40, 161-172.

Schemel L. E., Kimball B. A. and Bencala K. E. (2000) Colloid formation and metal transport through two mixing zones affected by acid mine drainage near Silverton, Colorado. Appl. Geochem. 15, 1003-1018.

Shirahata H., Elias R. W. and Patterson C. C. (1980) Chronological variations in concentrations and isotopic compositions of anthropogenic lead in sediments of a remote subalpine pond. Geochim. Cosmochim. Acta 44, 149-162.

Steding D. J., Dunlap C. E. and Flegal A. R. (2000) New isotopic evidence for chronic lead contamination in San Francisco Bay: implications for the persistence of past industrial lead emissions in the biosphere. Proc. Natl. Acad. Sci. USA 97(21), 1118111186.

Thomann R. V. and Mueller J. A. (1987) Principles of Surface Water Quality Modeling and Control. HarperCollins Publishers, $644 \mathrm{p}$.

Wenner J. M. and Coleman D. S. (2004) Magma mixing and cretaceous crustal growth: Geology and geochemistry of granites in the central Sierra Nevada Batholith, California. Int. Geol. Rev. 46, 880-903.

Associate editor: Lesley A. Warren 